\title{
Sex Hormones Effects on the Control of Menopausal Asthma
}

S. Aissani ${ }^{1^{*}}$, I. Ararem ${ }^{2}$, H. Haouichat ${ }^{3}$, M.E. Haffaf ${ }^{4}$ and A. Zitouni ${ }^{1}$

${ }^{1}$ Department of Pulmonary Service, Mohammed Seghir El Nekkache Hospital, Algeria

${ }^{2}$ Department of Preventive Medicine, Mohammed Seghir El Nekkache Hospital, Algeria

${ }^{3}$ Department of Pneumology of Mohammed Seghir El Nekkache Hospital, Algeria

${ }^{4}$ Department of Nuclear Medicine, Mohammed Seghir El Nekkache Hospital, Algeria

*Corresponding author: S. Aissani, Department of Pulmonary Service, Mohammed Seghir El Nekkache Hospital, Algeria, E-mail: dr_s.aissani@hotmail.fr

Received date: March 16, 2018; Accepted date: March 23, 2018; Published date: March 29, 2018

Copyright: (C) 2018 Aissani S, et al. This is an open-access article distributed under the terms of the Creative Commons Attribution License, which permits unrestricted use, distribution, and reproduction in any medium, provided the original author and source are credited.

\begin{abstract}
Introduction: Asthma can persist after menopause but can also occur in pre- or post-menopause. The aging of the bronchial tree and the fall of the hormones during the menopause can influence the control of asthma.

Methods and methods: This is a prospective descriptive study from 2011 to 2017. It involved 106 postmenopausal asthmatic patients divided into two groups according to the onset of asthma before or after menopause. These women received prick tests for the most common allergens, spirometry and a dosage of progesterone and estradiol.
\end{abstract}

Results: These asthmatics are 45 to 70 years old with an average age of $58.39 \pm 7.32$ years. They have an average body mass index (BMI) of $28.83 \pm 5.68 \mathrm{~kg} / \mathrm{m}^{2}$. The almost exclusively passive smoking exposure is found in more than half of the cases.

When asthma occurs after menopause (24 patients), the average BMI is $29.12 \pm 4.46 \mathrm{~kg} / \mathrm{m}^{2}$. These women were postmenopausal earlier in $12.5 \%$ of cases and had positive skin tests in only $23.8 \%$ of cases. When asthma occurred before menopause (82 patients), the average BMI was $28.87 \pm 5.06 \mathrm{~kg} / \mathrm{m}^{2}$. These women have been menopausal at normal age but have decreased respiratory function. Overall uncontrolled asthma was found in $58.5 \%$ of patients with postmenopausal asthma and $43.9 \%$ in those with pre-menopausal asthma with a statistically significant difference $(p=0.04)$.

There was no significant difference in hormone levels studied between the two groups. But the severity and uncontrolled asthma are associated with significantly higher estradiol levels.

Conclusion: The involvement of estrogen in the control and severity of asthma is not negligible in this study. The possible interaction of these hormones with other field factors such as smoking exposure and obesity is strongly suspected.

Keywords: Asthma; Woman; Menopause; Control; Obesity; Estradiol

\section{Introduction}

Asthma can persist after menopause but can also occur in pre- or post-menopause. During this period of the genital life, the asthma coincides with the aging of the respiratory system and the fall of the sex hormones, causing these two factors to be suspected in the uncontrolled asthma. The purpose of our study is search the characteristics of stable menopausal asthma and to determine women at risk of uncontrolled asthma and women who risk asthma after menopause based on sex hormone levels.

\section{Methods}

Prospective descriptive study from 2011 to 2017. It covered 106 women with menopausal asthma, aged 45 to 70 years. They are divided into 2 groups according to the onset of asthma before (77.35\%) or after menopause (22.64\%). They benefited from prick tests for the most common allergens, spirometry and an assay of progesterone and estradiol by radioimmunoassay. We excluded the thyroid, adrenal and gynecological pathologies that can influence the hormone levels as well as cardiovascular pathologies that can increase dyspnea. Final exploitation and data analysis used EPI-DATA analysis software and EPI-INFO6.

\section{Results}

The average age of the study population is $58.39 \pm 7.32$ years. The mean age in the front asthma group is $57.51 \pm 7.13$ years and in the postmenopausal asthma group is $61.38 \pm 7.35$ years old and the difference is statistically significant $(\mathrm{p}=0.02)$. The average duration of asthma is $25.21 \pm 13.7$ years when asthma appeared before menopause. It is $6.75 \pm 4.04$ years old when asthma appears after menopause and the difference is significant $(\mathrm{p}=10-4)$. 


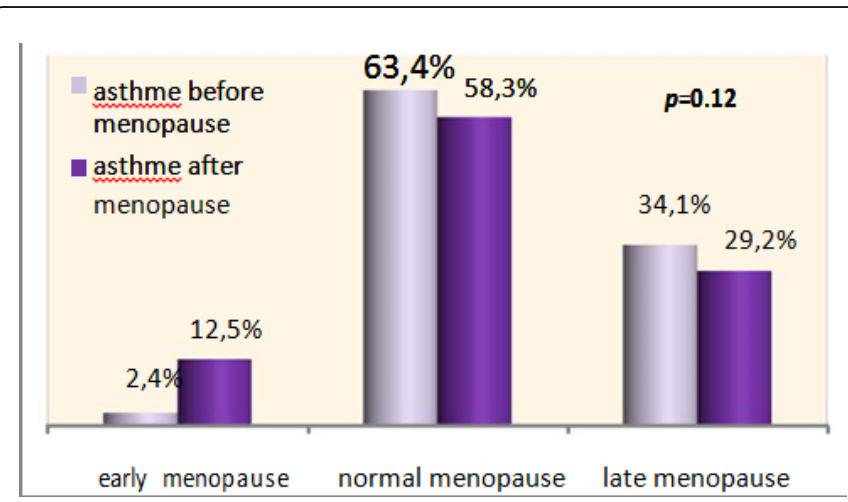

Figure 1: Age of menopause

Most women were menopausal at normal ages between 45 and 55 years of age (Figure 1). Early menopause is more common in postmenopausal asthma in $12.5 \%$ of patients. As for late menopause, it is more common in case of asthma before menopause: $34.1 \%$ of cases (Figure 1). The average age of menopause in pre-menopausal asthma is $49.04 \pm 4.36$ years and in menopausal asthma, it is $46.04 \pm 6.34$ years with a statistically significant difference $(\mathrm{p}=0.009)$.

The average body mass index (BMI) of the study population is 28.83 $\pm 5.68 \mathrm{~kg} / \mathrm{m}^{2}$. In case of asthma after menopause, overweight is found in $45.8 \%$ of cases and obesity in $37.5 \%$ of cases (Figure 2). In case of asthma before menopause, overweight is found in $40.2 \%$ of cases and obesity in $35.5 \%$ of cases. In addition, the average body mass index (BMI) for asthma before menopause is $28.87 \pm 5.06 \mathrm{~kg} / \mathrm{m}^{2}$ and it is $29.12 \pm 4.46 \mathrm{~kg} / \mathrm{m}^{2}$ in case of asthma after menopause $(\mathrm{p}=0.82)$.

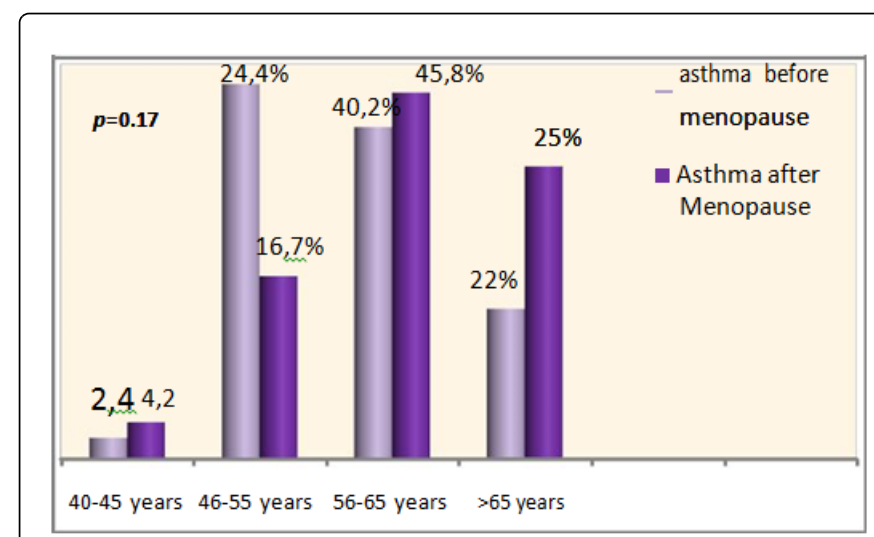

Figure 2: Body mass index (BMI)

There was no difference between the two groups of asthma in terms of exposure to tobacco and biomass. There is also no difference in the nature and number of comorbidities (Table 1). Moderate asthma dominates in both groups, and severe asthma is more common in those with pre-menopausal asthma (Figure 3).

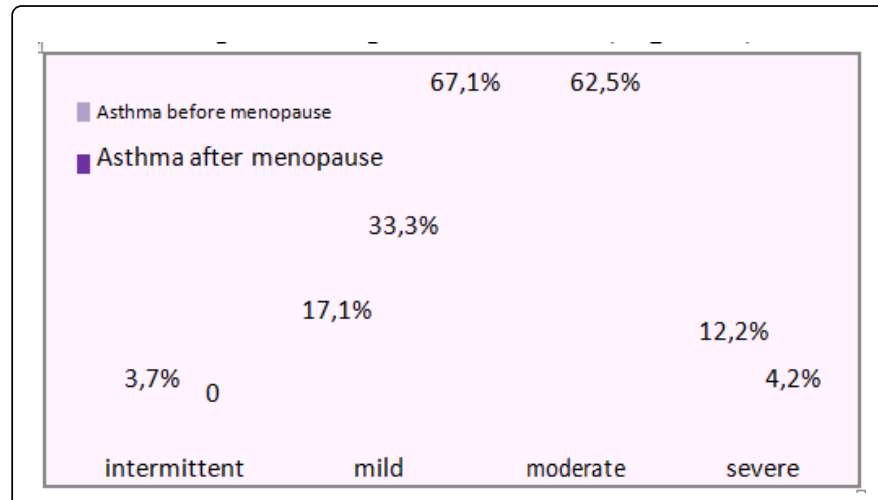

Figure 3: Asthma severity

\begin{tabular}{|l|l|l|l|l|}
\hline & & $\begin{array}{l}\text { Before } \\
\text { menopause } \\
(\mathbf{N = 8 2})\end{array}$ & $\begin{array}{l}\text { After } \\
\text { menopause } \\
(\mathbf{N}=24)\end{array}$ & P \\
\hline \multirow{2}{*}{ Smoke } & Smoke exposure & $37(41.12 \%)$ & $13(54.16 \%)$ & 0.75 \\
\cline { 2 - 5 } & $\begin{array}{l}\text {-ACTIF } \\
\text {-PASSIF }\end{array}$ & $\begin{array}{l}2(2.4 \%) \\
35(46.3 \%)\end{array}$ & $\begin{array}{l}1(4.2 \%) \\
12(50 \%)\end{array}$ & 0.83 \\
\hline \multirow{2}{*}{ Biomass exposure } & $14(17.1 \%)$ & $5(20.8 \%)$ & 0.67 \\
\hline \multirow{2}{*}{ Comorbidition } & Presents & $63(76.8 \%)$ & $21(87.5 \%)$ & 0.25 \\
\cline { 2 - 6 } & $\begin{array}{l}\text { Gastroesophage } \\
\text { al reflux }\end{array}$ & $51(62.2 \%)$ & $18(75 \%)$ & 0.24 \\
\cline { 2 - 5 } & Rhino-sinusitis & $78(95.1 \%)$ & $21(87.5 \%)$ & 0.13 \\
\cline { 2 - 5 } & Conjunctivitis & $59(72 \%)$ & $16(66.7 \%)$ & 0.61 \\
\hline
\end{tabular}

Table 1: Smoke and comorbidities

Uncontrolled asthma is frequently found in women with premenopausal asthma (Figure 4).

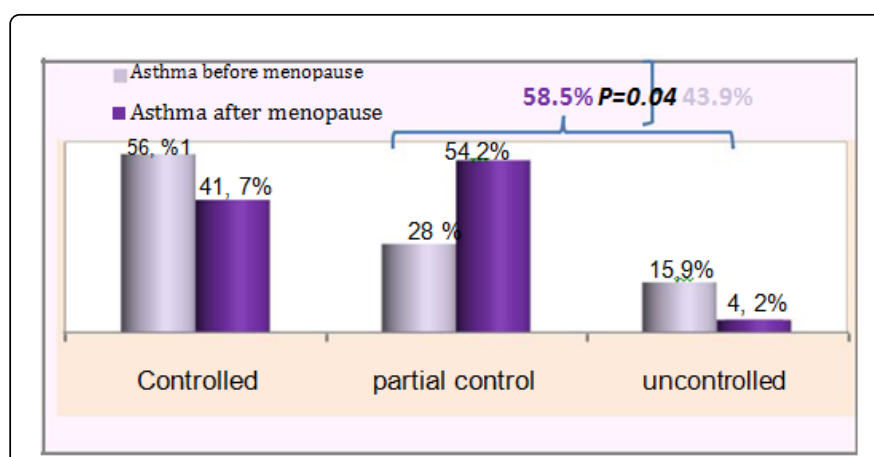

Figure 4: Asthma control

When grouping patients with partially controlled asthma and uncontrolled asthma, overall non-control was found in $58.5 \%$ of patients with asthma after menopause and $43.9 \%$ in the other group with a statistically significant difference $(\mathrm{p}=0.04)$. This no control is more common in women over 65 (35.7\% of cases) and in the age group $45-55$ in $42.9 \%$ of cases (Figure 5). 
Page 3 of 4

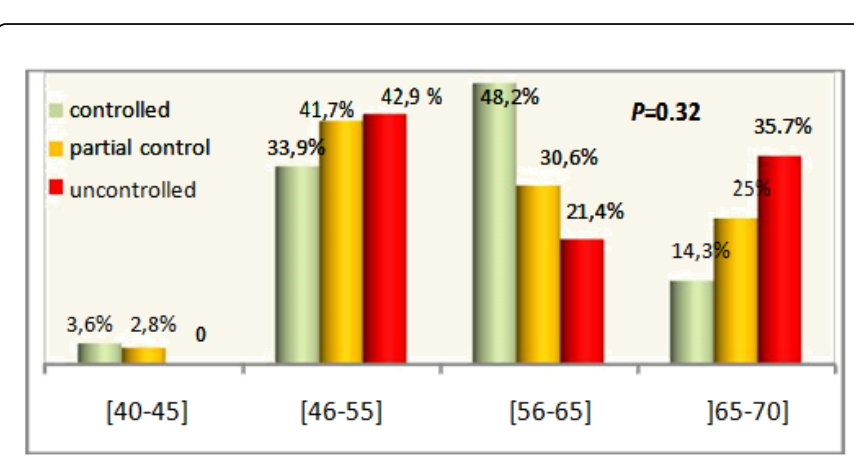

Figure 5: Asthma control according to age groups

The concept of familial atrophy was found in $87.8 \%$ of women who had asthma before menopause and in $83.3 \%$ of cases whose asthma appeared after menopause $(\mathrm{p}=0.59)$. Skin tests were performed in only 80 women (75.47\%): 59 asthmatics who had pre-menopausal asthma (71.95\%) and a positive result in $54.2 \%$ and were did in 21 asthmatics with asthma after menopause (87.5\%) with positive tests in only $23.8 \%$ and the difference between the two groups is statistically significant $(\mathrm{p}=0.01)$. The analysis of spirometry found a lower rate of FEV1/CV ratio and peripheral flow rates (FEF 50, FEF25 and FEF 25-75) in asthma before menopause (Table 2).

\begin{tabular}{|l|l|l|l|}
\hline & $\begin{array}{l}\text { Asthma } \\
\text { menopause Vefore } \\
\text { (IC 95\%) (N=82) }\end{array}$ & $\begin{array}{l}\text { Asthma } \\
\text { menopause Value (IC } \\
\mathbf{9 5 \% )}(\mathbf{N}=\mathbf{2 4})\end{array}$ & P \\
\hline VC (I) & $2.44(2.33-2.55)$ & $2.34(2.08-2.59)$ & 0.39 \\
\hline FVC (I) & $2.40(2.29-2.5)$ & $2.31(2.05-2.57)$ & 0.46 \\
\hline PEF (I/s) & $4.90(4.64-5.16)$ & $4.95(4.3-5.59)$ & 0.87 \\
\hline FEV1 (I) & $1.94(1.83-2.04)$ & $2.01(1.78-2.25)$ & 0.46 \\
\hline FEV1/VC (\%) & $79.62[77.81-86]$ & $86.67(83.05-90.28)$ & 0.002 \\
\hline FEF75 (I) & $4.01(3.69-4.34)$ & $4.57(3.89-5.25)$ & 0.11 \\
\hline FEF50 (I) & $2.41(2.14-2.67)$ & $2.95(2.45-3.45)$ & 0.05 \\
\hline FEF25 (I) & $0.95(0.83-1.08)$ & $1.31(0.96-1.65)$ & 0.01 \\
\hline FEF25-75 (I) & $2.05(1.82-2.28)$ & $2.56(2.09-3.05)$ & 0.03 \\
\hline
\end{tabular}

Table 2: Spirometer results

The average progesterone level in postmenopausal asthmatics is normal by laboratory standards. On the other hand, the average level of estradiol is higher, especially among those who have had asthma after menopause and are at a distance from the beginning of menopause. In addition, the mean estradiol level of the study population is greater than the mean value of the normal population (Table 3).

\begin{tabular}{|l|l|l|l|}
\hline & $\begin{array}{l}\text { Asthma before } \\
\text { menopause Value } \\
\text { (IC 95\%) (N=82) }\end{array}$ & $\begin{array}{l}\text { Asthma after } \\
\text { menopause } \\
\text { Value (IC 95\%) } \\
(\mathbf{N = 2 4 )}\end{array}$ & $\mathbf{P}$ \\
\hline Progesterone (nmol/l) & $0.65(0.23-1.08)$ & $0.33(0.13-0.61)$ & 0.50. \\
\hline
\end{tabular}

\begin{tabular}{|l|l|l|l|}
\hline $\begin{array}{l}\text { Normal value of } \\
\text { progesterone }\end{array}$ & $1(0.5-5.20)$ & \multicolumn{2}{|l|}{} \\
\hline Estradiol $(\mathbf{p g} / \mathrm{ml})$ & $\begin{array}{l}135.49 \\
(32.52-238.41)\end{array}$ & $\begin{array}{l}62.42 \\
(38.10-86.74)\end{array}$ & 0.45 \\
\hline $\begin{array}{l}\text { Normal value of } \\
\text { Estradiol }\end{array}$ & $26(11-50)$ & & \\
\hline
\end{tabular}

Table 3: Hormone level

The mean level of estradiol is significantly higher in severe and/or uncontrolled asthma. Progesterone levels were not associated with the severity stages of asthma (Tables 4 and 5 ).

\begin{tabular}{|c|c|c|c|c|c|}
\hline & $\begin{array}{l}\text { Intermitten } \\
\mathrm{t}(\mathrm{IC} 95 \%) \\
\mathrm{N}=3\end{array}$ & $\begin{array}{l}\text { Mild (IC } \\
95 \% \text { ) } N=3\end{array}$ & $\begin{array}{l}\text { Moderate } \\
\text { (IC 95\%) } \\
\mathrm{N}=3\end{array}$ & $\begin{array}{l}\text { Severe (IC } \\
95 \%) \mathrm{N}=3\end{array}$ & $\mathbf{P}$ \\
\hline $\begin{array}{l}\text { Progesterone } \\
\text { (nmol/l) }\end{array}$ & $\begin{array}{l}1.01 \\
(1.25-3.47)\end{array}$ & $\begin{array}{l}0.73 \\
(0.50-0.95)\end{array}$ & $\begin{array}{l}1.19 \\
(0.70-1.67)\end{array}$ & $\begin{array}{l}0.78 \\
(0.35-1.2)\end{array}$ & 0.67 \\
\hline $\begin{array}{l}\text { Estradiol } \\
(\mathrm{pg} / \mathrm{ml})\end{array}$ & $\begin{array}{l}159.77 \\
(50-720.01)\end{array}$ & $\begin{array}{l}73.94 \\
(39.11-108.7 \\
8)\end{array}$ & $\begin{array}{l}56.45 \\
(43.49-69.4 \\
1)\end{array}$ & $\begin{array}{l}221.99 \\
(117.16-482 . \\
9)\end{array}$ & $\begin{array}{l}0.00 \\
3\end{array}$ \\
\hline
\end{tabular}

Table 4: Hormone levels according to the asthma severity

\begin{tabular}{|c|c|c|c|c|}
\hline & $\begin{array}{l}\text { Controlled } \\
\text { Value (IC 95\%) } \\
(\mathrm{N}=56)\end{array}$ & $\begin{array}{l}\text { Partially } \\
\text { control Value } \\
\text { (IC } 95 \%) \quad N=36\end{array}$ & $\begin{array}{l}\text { Uncontrolled } \\
\text { Value (IC } \\
95 \%) \mathrm{N}=14\end{array}$ & $\mathbf{P}$ \\
\hline $\begin{array}{l}\text { Progesterone } \\
\text { (nmol/l) }\end{array}$ & $\begin{array}{l}0.83 \\
(0.65-1.02)\end{array}$ & $\begin{array}{l}1.16 \\
(0.53-1.78)\end{array}$ & $1.5(0.33-3.52)$ & 0.23 \\
\hline Estradiol (pg/ml) & $\begin{array}{l}69.94 \\
(46.62-88.71)\end{array}$ & $\begin{array}{l}60.06 \\
(39.83-80.29)\end{array}$ & $\begin{array}{l}181.98 \\
(20-383.98)\end{array}$ & 0.01 \\
\hline
\end{tabular}

Table 5: Hormone levels according to the asthma control

\section{Discussion}

This work made the following observations: Asthma is more severe and less controlled in women who have had asthma after menopause; what has already been reported by GIBBS [1] and FOSCHINO [2].

Uncontrolled asthma is more common in women aged 46 to 55 , generally corresponding to the age of onset of menopause $(42.9 \%$ of cases). It is also common in people over 65 who are far from the beginning of menopause (35.7\% of cases). This makes it possible to consider these two age groups as two particular phenotypes in the severity and uncontrolled asthma.

Uncontrolled asthma is due to several factors including obesity. The majority of menopausal asthmatics are overweight or obese. The average body mass index is higher for asthma after menopause. This excess weight is one of the reasons for the non-control observed in the menopause since it has been shown for several years that overweight and obesity are responsible for the severity and uncontrolled asthma [3-5]. It has even been shown by TRIEBNER that the risk of asthma after menopause is related to obesity and that this risk is higher when asthma appears at a distance from menopause with a higher Odds Ratio of 26.15 [IC 95\%: 2.62-261.13]. This makes it possible to consider the combination of obesity and asthma after menopause as a particular phenotype [6]. 
Tobacco exposure is already mentioned in the literature as a factor influencing the control of asthma [7,8]. This was a passive smoking exposure in the majority of our patients (Table 1). Tobacco may be a factor responsible for the precocity of menopause [9]. It leads to an increase in bronchial hyper reactivity with the risk of asthma [8]. This may partly explain why asthma occurred after menopause, as $54.16 \%$ of women with postmenopausal asthma had tobacco exposure. These women were postmenopausal earlier than those who had asthma before menopause and who were less exposed to tobacco (exposure in $41.12 \%$ of cases).

In addition, asthma after menopause is often non-allergic. This has already been reported in the literature [10-13] and found in our work. For this reason, the onset of asthma after menopause often causes other non-allergic factors such as obesity, smoking, external environmental and household factors to be suspected. It may even be secondary to the effect of aging on the respiratory system and/or the age of the disease, especially since there has been a significant decrease in respiratory function in the case of asthma before menopause. The difference between asthma groups before and after menopause exists clinically and allergically but does not by itself explain the occurrence of asthma after menopause. A hormonal cause is possible but no significant difference in hormone levels was found between the asthma groups before and after menopause.

Whether it is asthma before or after menopause, the average levels of estradiol are higher than the average rate of the laboratory standard. WEINSTEIN found lower rates in postmenopausal asthmatics compared with non-asthmatics with an average rate of $4.4 \mathrm{pg} / \mathrm{ml}$ [14]. This result is not contradictory to ours. It is explained by the lower average age of our patients compared to that of WEINSTEIN (58.39 \pm 7.32 years vs. $67.8 \pm 7.7$ years), since the further away the peri menopause and the lower the estradiol level is high.

Other authors such as GRAHAM BARR [15] and KOS-KUDLA [16] have found low levels of estradiol in menopausal asthmatics. But these authors have measured the sex hormones in asthmatics with hormonal substitution, which could influence the result. In our series, only one patient had received hormone replacement therapy, which does not allow conclusions to be drawn about the effect of hormonal substitution on asthma.

The high mean estradiol level observed in our menopausal patients may be due to the transformation of androgens into estrogens from adipose tissue $[17,18]$ in our overweight or obese patients fat is very important.

In addition, the severity and uncontrolled asthma is significantly associated with a higher level of estradiol, suggesting that the proinflammation effect of high estradiol [19]. Thus obesity has a dual influence on bronchial inflammation by action on adipocytes to stimulate mediators of inflammation [20] and on the indirect increase of estradiol levels by transformation of androgens into estrogens from the tissue adipose [18]. The consequence would be an increase in bronchial inflammation with uncontrolled asthma.

\section{Conclusion}

In this work, there was no individuality in terms of hormonal dosage between those who had asthma after or after menopause. But asthma severity and non-control are significantly related to higher levels of estradiol suggesting the involvement of estradiol in the pathophysiology of postmenopausal asthma. While obesity and smoking have been found in our work as factors associated with asthma after menopause, the interaction of these two factors with sex hormones may explain the onset of asthma after menopause. Postmenopausal women's asthma is unique because of the association of several factors: comorbidities, obesity, lack of physical activity and deterioration of the psyche that must be taken into account.

\section{References}

1. Gibbs CJ, Coutts II, Lock R, Finnegan OC, White RJ (1984) Premenstrual exacerbation of asthma. Thorax 39: 833-836.

2. Foschino Barbaro MP, Costa VR, Resta O, Prato R, Spanevello A, et al. (2010) Menopausal asthma: A new biological phenotype? Allergy Eur J Allergy Clin Immunol. 65: 1306-1312.

3. Hersoug LG, Linneberg A (2007) The link between the epidemics of obesity and allergic diseases: Does obesity induce decreased immune tolerance? Allergy Eur J Allergy Clin Immunol 62: 1205-1213.

4. Chanez P, Wenzel S (2008) Asthme sévère. Press Medicale 37: 99-105.

5. Saint-Pierre P, Bourdin A, Chanez P, Daures JP, Godard P (2006) Are overweight asthmatics more difficult to control? Allergy Eur J Allergy Clin Immunol 61: 79-84.

6. Triebner K, Johannessen A, Puggini L, Benediktsdóttir B, Bertelsen RJ, et al. (2016) Menopause as a predictor of new-onset asthma: A longitudinal Northern European population study. J Allergy Clin Immunol 137: 5057.

7. Charpentier C (2016) Asthme et tabac. Rev Fr Allergol 56: 165-168.

8. Piipari R, Jaakkola JJK, Jaakkola N, Jaakkola MS (2004) Smoking and asthma in adults. Eur Respir J 24: 734-739.

9. Kaufman DW, Slone D, Miettinen OS, Shapiro S (1980) Cigarette Smoking and Age at Natural Menopause. Am J Public Health 70: 420422.

10. Balzano G, Fuschillo S, Melillo G, Bonini S (2001) Asthma and sex hormones. Allergy 56: 13- 20.

11. Van Den Berge M, Heijink HI, Van Oosterhout AJM, Postma DS (2009) The role of female sex hormones in the development and severity of allergic and non-allergic asthma. Clin Exp Allergy 39: 1477-1481.

12. Zein J, Comhair S, Bleecker E, Busse W, Calhoun W, et al. (2014) The Effect of Aging and Menopause on Asthma Severity in Women. CHEST 145: 984-992.

13. Leynaert B. AANAA: Determinants personnels et environnementaux de l'asthme allergique et non allergique de ladulte _ etude longitudinale européenne 1-7.

14. Weinstein RE, Lobocki CA, Gravett S, Hum H, Negrich R, et al. (1996) Clinical aspects of allergic disease absence of glucocorticoid suppression in postmenopausal asthmatic women. J Allergy 97: 1-8.

15. Graham BR, Catherine CW, Francine G, Samuel S, Meir JS, et al. (2004) Prospective study of postmenopausal hormone use and newly diagnosed asthma and chronic obstructive pulmonary disease. Arch Intern Med 164: 379-386.

16. Kos KB, Ostrowska Z, Marek B, Ciesielska Kopacz N, Sieminska L, et al. (2000) Hormone replacement therapy in postmenopausal asthmatic women. J Clin Pharm Ther 25: 461-466.

17. Ailhaud G (1998) Ladipocyte, cellule secretrice et endocrine. Medecine/ Sciences. 14: 858- 864 .

18. Zeitoun KM, Bulun SE (1999) Aromatase: A key molecule in the pathophysiology of endometriosis and a therapeutic target. Fertil Steril 72: 961-969.

19. Townsend EA, Miller VM, Prakash YS (2012) Sex differences and sex steroids in lung health and disease. Endocr Rev 33: 1-47.

20. Sismanopoulos N, Delivanis D, Mavrommati D, Hatziagelaki E, Conti P (2013) Do mast cells link obesity and asthma囚? Eur J allergy Clin Immunol 68: 8-15. 